M. Tieira Salividade
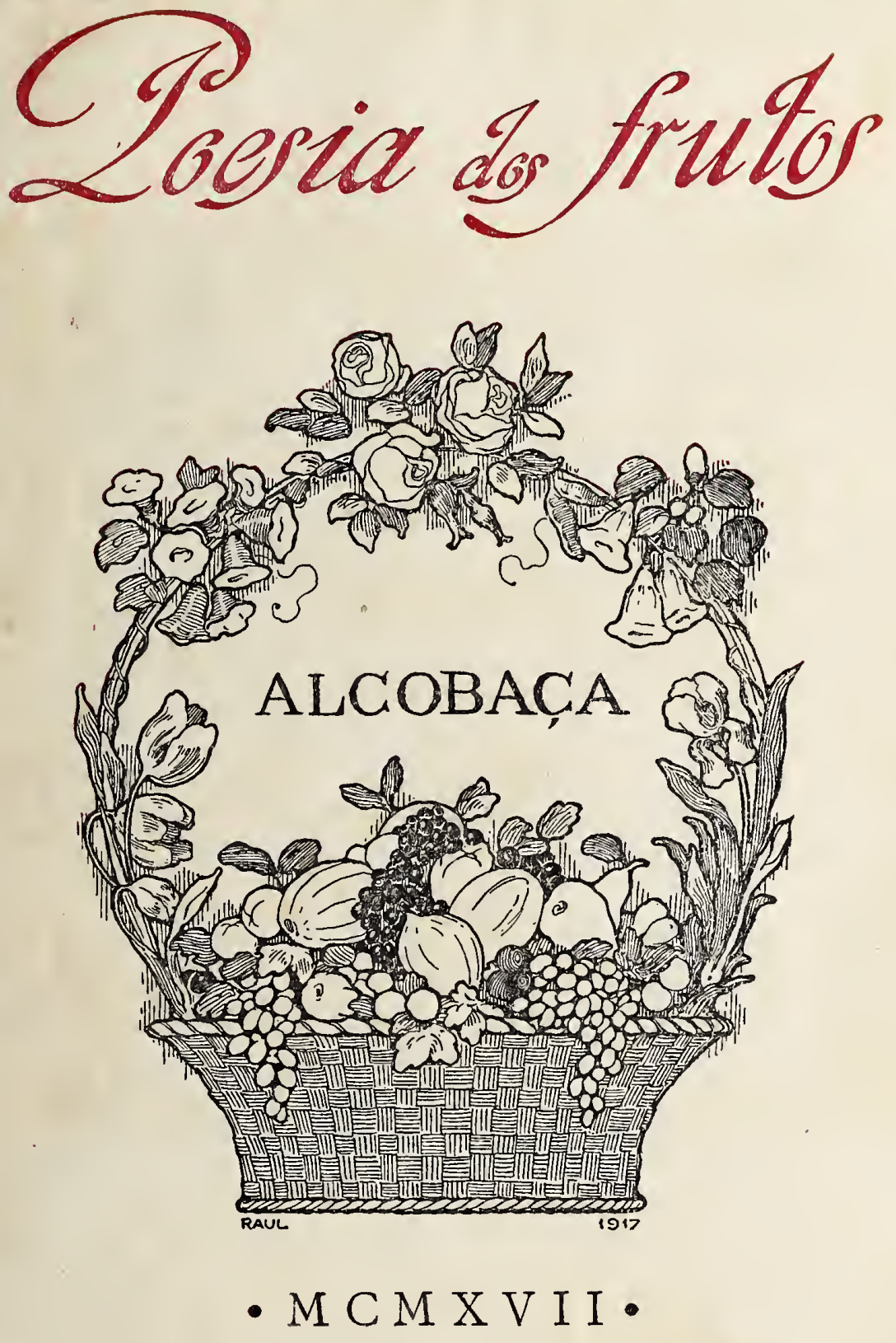

Digitized by the Internet Archive in 2016 


\section{Poesia dos Frutos}

Palavras lidas ua FESTA DOS FRUTOS, que se realisou no Claustro de D. Donis, para solenisar a exposiçáo pomologica de llcobaça. com assistencia dos ilustres Presidente da Republica Portugyesa, sir. dr. Tcofilo Braga, e ditnistro do Fomento, Sr. dr. Manuel Monteiro.

NOITE DE 26 1DE SETEMBRO DE 1915 


\section{DO AUTOR:}

GOTTAS D'AGUA - Versos - 1886.

AS ROSAS - Palavras lidas ma "Festa das Rosas", realisada no Claustro de D. Denis-1014. Fora do mercado.

\section{PREHISTORIA E HISTORIA}

O MOSTEIRO D'alCOBACA - Notas - 1885.

ROTEIRO ARCHEOLOGICOO H'AICOBACA E COUTOS $-\mathbf{I} 891$.

I BATALHA DALJUBARROTA - Carta ao Sr, Oliveira Martins - 1891 .

GRUTAS D'AICOBACA - Com 236 gravuras - 190r. Sefa rala da "Portrgatia".

ALCOBACA D'OUTRO TEMPO - No Relatorio da Exposiçáo Alcobacense, do Dr. Francisco Zagalo - 1906.

IGNEZ IIE CASTRO E PEDRO O CRT', PERANTE A ICO. NOGRAPHIA DOS SELS TUMULOS-Com 36 fotogravuras -1910.

ALCOBACA - Na Arte c Nature $\mathrm{cm}$ Portugal.

AS FRUTAS 1'ALCOBACA - 1912.

O CULTO JA ARVORE - Igr $3-20^{x}$ ediçăo.

ALCOBACA E BATALHA - W. Beckford - Trajuçăo com Joaquim Lucio Lobo. Fora do mercado.

1). FR. ESTEVAM MARTINS E AS ESCOLAS PUBLICAS DO MIOS'EEIRO D ALCOBACA - Separata dos "Traba. thos da Academia de Sciencias de I'ortugal».

\section{ETHNOGRAPHIA}

NOTE ITHNOGRAPHIQUE SUR IES CHIFFRES USIS DANS LES PRESSOIRS D'OLIVES DANS L'ARRONDISSFMINT DALCOBACA - 1892 .

1.A TAILLE HU SILEX - 1 W 33 .

AS ROCAS DA MINHA TFRRA - InOS.

\section{A ENTRAR NO PRELO}

MOSTELO E COUTOS D'ALCOBACA - Com muiras gra. vuras sobre arte, ethnographia, archeologia e historia. 


\section{In. Tieira Tativiade}
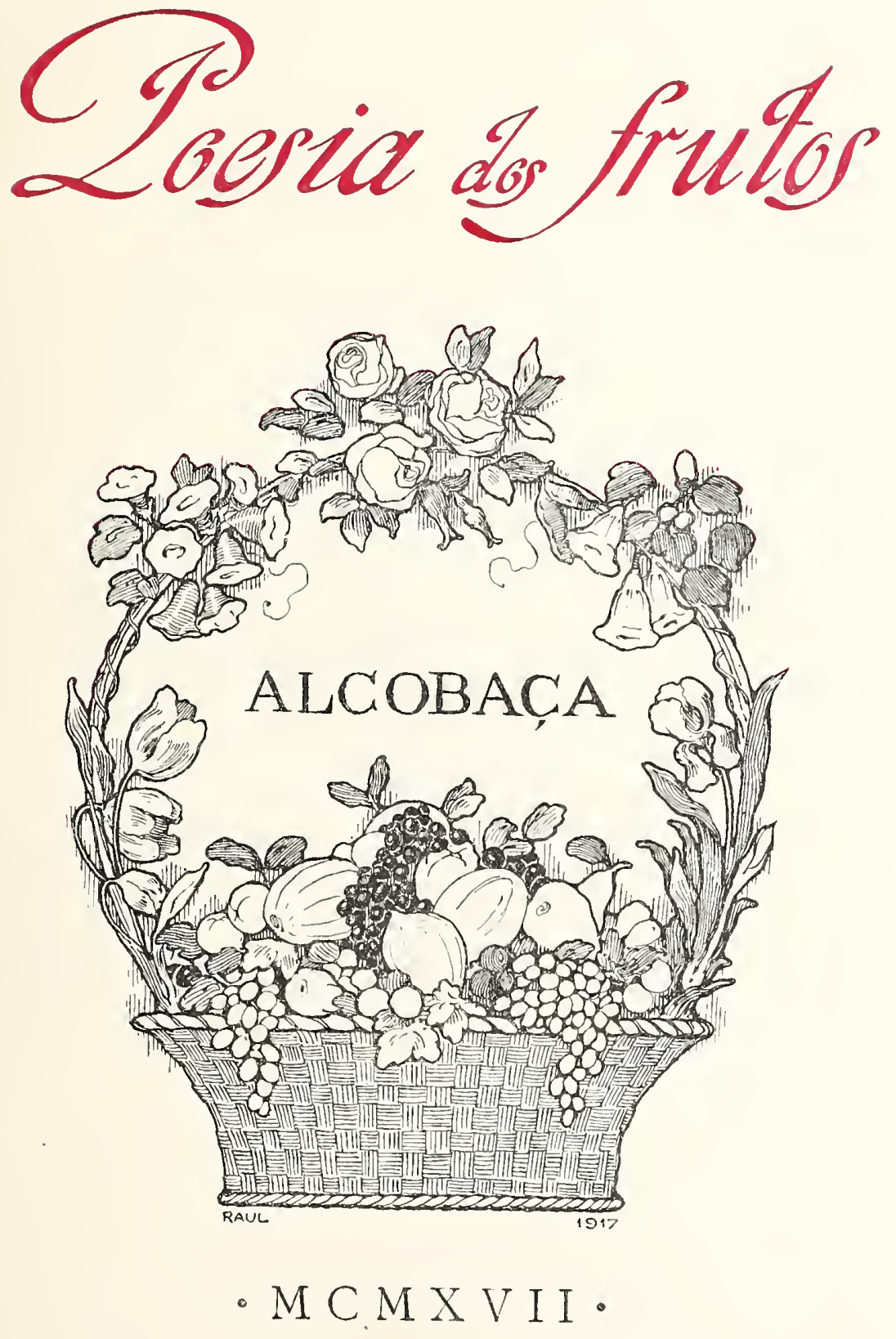
TIRAGEM DE TRE-

ZENTOS EXEM-

PLARES, FÓRA DO

MERCADO.

N. $2 / 2$

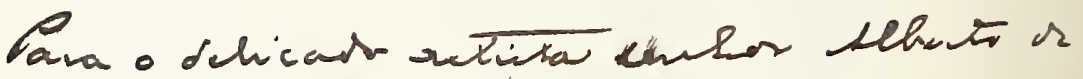

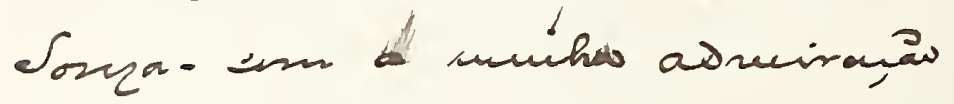

ruañ a ISIY

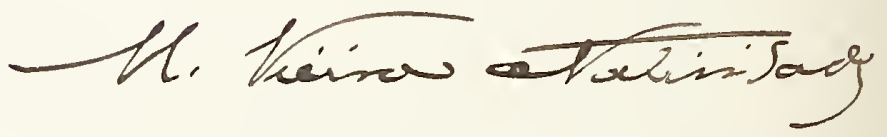


Senhor Presidente da Republica Portuguesa Senhor Ministro do Fomento

Minhas senhoras, meus senhores

GRANIE BANQTETE DA NATUREZA-
é uma frase que os poetas refe-
rem sem the atribuir uma exacta
significação. Traduz-se, na sua
enorme complexidade, com o conhecimento de muitas sciencias, porque a sua vastidão é tamanha que absorve toda a sciencia da vida, todo o misterio da criação.

Banquete da natureza é toda a vida do mundo organico; é a morte, é o despojo de tudo o que foi criado. E' a seiva das plantas, é o sangue dos animais.

Banquete da natureza é a planta vivendo sobre o cadaver de outra planta, é a evolução da flôr e do fruto, é o perfume 
que nos delicia, é o veneno vegetal que nos mata, é o carnivoro vivendo á custa doutro animal, é o insecto entomofogo devorando outro insecto ou vivendo nele, é a luta pela vida, directa, cruel, indispen. savel, é viver sobre o que morreu, é viver do que foi sacrificado á mais cruel das voracidades.

Banquete da natureza é a decomposição da vida, é a transformação no humus que vai dar á terra a sua esgotada fertilidade.

Banquete da natureza é o sacrificio de uma parte do mundo organico á outra parte, é o sacrificio de vidas para que outras vidas se mantenham; é a complexidade que se póde chamar a evolução da materia ou a grande reacçáo quimica de uma enormidade cosmica.

Sem entrarmos na apreciação filosofica de todos estes factos, tiraremos daí a parte destinada ao nosso fim, e deixaremos todos esses dramas, todos esses poemas e elegias para os poetas e para os sabios.

Tomaremos o fruto para nosso tema, e nem outra coisa podia ser, visto que são os frutos o orago desta festa.

Sobre aquele extraordinario caso que a sonhadora biblia nos descreve - o triste 
pecado da mãe Eva-parece que devia nascer o odio pelo fruto, porque dele nos advieram as durezas do trabalho e as crueldades da vida. Mas-- perante esse caso de feminina curiosidade - eu abençôo o pecado que nos veio trazer os misterios do amor e as doçuras da familia.

Descendente de Adão ou de multiplas e variadas origens, foi com os frutos e o machado de silex que o homem conseguiu salvar-se dos perigos da vida, perigos a que, certamente, não resistiram animais muito mais fortes.

A alimentação e a defeza eram os escolhos unicos da vida. Series de animais se transformaram pelas contingencias da alimentação, ao passo que outros tombaram para sempre, deixando como documento da sua existencia os longos esqueletos que a terra transformou em pedra, para deixar lèr no futuro preciosas paginas de extinta criação.

Quando o primeiro homem levantou a sua bela cabeça e aprumou o seu corpo veloso e escuro, sem consciencia do seu fim, sem preocupaçóes de ascendencia, sem ancias de gloria postuma, não teve que trabalhar para comer: - á sua volta 
as arvores estendiam carinhosamente os braços vergados pelo peso dos mais perfumados frutos.

$\mathrm{E}$, se ainda hoje é problematico o ponto inicial da sua origem, isto é, onde se operou o ultimo cruzamento ou a ultima evolução que o produziu, bem aceita o meu espirito que. só o podemos procurar numa região muito proxima do equador, onde uma temperatura permanente o deixasse evoluir e crescer, e onde as arvores, numa eterna primavera, eternamente se cobrem de frutos.

O homem nasceu frutivoro:-indicamno os seus instintos e a sua provavel ascendencia, e só naquela zona ele achava, sem trabalho, a sua alimentaçáo permanente.

As suas tendencias nómadas fizeramno afastar desse meio; e foi nas crises do seu longo migrar que se viu obrigado a sofrer as mais inesperadas modificaçóes. Fui quando a alimentação the faltou que o seu paladar teve de aceitar a novidade dos alimentos mais variados e que a caça e at pesca surgiram como base das mais primitivas industrias. Foi a mais violenta das crises da fome que o levaram á pratica 


\section{( I I )}

do grande crime social chamado antropofagia.

As necessidades da vida trazen as curiosidades da observação; e, mercê dessa observaçáo, lenta mas exacta, o homem aprende a maneira de suprir as faltas; estuda, observa e entende; e, como fruto dessa evolução mental, a sciencia economica nasce emparelhada com a previdencia.

Recolhem-se os frutos de maturação mais tardia; os bolbos e os tuberculos que a observação, pelas folhas, ensinára a conhecer, arrancam-se da terra; acondicionam-se as sementes para as provisóes do inverno. Nesta delicada operação alguns bagos caem na terra, e ali germinam, ali crescem e frutificam na mais bela e mais eloquente lição. Os bolbos e os tuberculos atiram para a luz do sol, no seu anceio de vida, a nobre riqueza das gemulas ger minadas.

O homem aproveitou essa lição, e, para que a provisão aumentasse, semeou, cultivou e colheu; e foi deste valioso trabalho que adveio o grande factor de progresso chamado - agricultura.

Inicialmente frutivoro, teve que variar 
- a sua alimentação, teve que prover ás necessidades que o esperavam nas suas longas e interminaveis migraçóes. Caminhava sem certo destino, como aves que periodicamente mudam de clima, mas sem a orientação e instinto delas; e assim foi transformando a sua maneira de ser primitiva e assim se foi adaptando ao meio em que se achava.

Nas tristes e violentas crises da fome aprendeu a ser carnivoro com o carnivoro com que lutava, aproveitou o instinto dos herbivoros e comeu vegetais e raizes.

Como nem sempre havia frutos na floresta, caçava para matar a fome, emquanto não aprendeu a organisar os rebanhos. Mas organisou-os, emfim, e na sua vida de nómada, já com esboços de estacionaria, travou conhecimentos mais largos com a vasta natureza e foi arquivando observaçóes e factos.

Um dia nasce na manada um animal mais lindo. O homem admira-o, estima-o, afaga-o. Esboça-se, assim, o amor delicado pelas coisas, e o lindo animal faz nas. cer no coração do homem as flôres mais perfumosas da ternura. $\mathrm{O}$ animal faz-se amigo do homem e a domesticidade inicia-se. 
Este simples facto, tão simples, tão natural, é uma das mais poderosas bases das mais cultas civilisaçócs:- o animal domesticado operou na vida do homem as transformações mais valiosas. Defendeu-o; alimentou-0; transportou-o; fez do nómada um sedentario, e o homem deixou de errar vagamente pelas montanhas e instalou-se nos abrigos que a natureza the oferecia.

Aquieta-se, então, o seu espirito, e aí, nesses abrigos, emquanto là fóra ruge o temporal e o raio fuzila, o espirito do homem faz o moroso inventario dos seus conhecimentos e a primeira nota de uma nitida civilisação surge triunfal, com as primei. ras noções de estetica na preferencia das côres, das fórmas e das coisas, com assomos de religião que o abrigo e o bemestar provocavam, com a constituição da colonia, que se abrigava nas regióes preferidas, representando desde já a base das familias e das futuras socicdades.

Desde entáo, e durante uns milenios de inviolavel historia, o homem progride. Esboçam-se as maravilhas do seu engenho, existe já a vida objectiva e subjectiva, ha o culto dos mortos, o culto dos astros, criam-se os deuses, inventa-se a escrita. 
A par destas notas de vida espiritual, ha tambem as duras preocupaçôes da vida pratica, onde imperam, como sempre, os cuidados de alimentação e de defeza.

Os frutos que a natureza the oferecia, num carinho de previdente mãe, seriam motivo de especial cuidado. Estudou-os. Reconheceu-os. Seleccionou-os. A arvore que os produzia distinguia-se no meio da floresta pelo porte e pela folhagem. Isolou-a das plantas que a afogavam, deu-lhe cuidados, carinho e ternura. Depois viu que, proximo dela, outras nasciam sobre os montóes de decomposta folhagem, e soube conhecê-las, ampará-las e defendêlas. Cuidadoso e diligente, ensaiou o transporte delas para o fundo dos vales mais proximos da sua morada e onde se mantinha uma perene frescura. A arvoresinha, rodeada do carinho mais intenso e da curiosidade mais justificada, ali cresceu, ali floriu e frutificou como precioso exemplo do trabalho.

E foi por esta fórma que se organisaram os primitivos pomares.

Os frutos melhoravam pela cultura, duplicavam o volume, multiplicavam as qualidades na doçura e no perfume, e as 


\section{( 15$)$}

arvoresinhas pagavam generosamente em requintes de doçura e aroma aqueles extremados carinhos.

Mas, essa arvoresinha, nascera de uma semente, e, o homem, vendo-o, aprendeu a semear a arvore.

Assim, era já facil agrupar á volta da gruta as arvores que, só muito longe, frutificavam.

O homem transportou as sementes e inventou a aclimação.

Em terrenos ricos e ferteis náo eram precisos cuidados: - a arvore lá crescia e frutificava como uma benção do céu, como uma filha da abundancia.

As grandes invasôes que sucederam aos periodos protohistoricos, a conquista e dominio romano, e, mais tarde, a invasão dos barbaros, foram novos elementos de adaptação e dispersão; e as plantas frutiferas e alimentares do norte e do oriente chegavam aos confins da Europa ocidental.

As primeiras caíam num clima mais suave e desdobravam-se nos mais preciosos frutos; as outras adaptavam-se ao meio e constituiam elementos de riqueza e de prosperidade.

Com o desenvolvimento do comercio 
estreitam-se as relaçóes do velho mundo; e, pouco a pouco, as mais raras variedades frutiferas espalham-se, igualmente, por todo o mundo conhecido e esperam as contingencias do clima para morrerem ou para frutificarem.

Senhoras e senhores:- A mais bela fase espiritual da humanidade foi aquela em que, durante os largos ciclos da paz, o homem se sentiu absorvido pela vida subjectiva, e, numa nobre liberdade de pensamento, criou essa vasta mitologia que é o maior poema de encanto que a humanidade tem escrito.

E é curioso de ver que essa fase mundial, que em todos os paizes e em todas as raças, com mais ou menos delicadeza e poesia, corresponde ao despertar da vida espiritual, é tão exacta, perante a evolução mental, como seria se entre todos os povos existissem prévias relaçóes.

Desse criar dos deuses, desse criar da alma, isto é, das causas que explicam e relacionam as coisas, nasceu o dualismo humano, a relaçãa entre o corpo e o espi- rito, a imortalidade da alma, que é um sonho da mais vibrante poesia. 


\section{( 17 )}

Nesse ciclo de vida mental adorou o que era belo, adorou o que era grande, adorou o que era bom:- o sol, a lua, a agua, a terra, as estrelas, as arvores, o pão e os frutos; o sol que lhe mostrava as asperezas do caminho, que o alegrava e aquecia, a lua que, na negra solidão da noite, the trazia o descanço e a vida feliz dos sonhos, a agua que lhe mitigava a sêde, a terra que lhe dava as arvores e o abrigo, as estrelas que o encantavam, as arvores que lhe davam as armas e a sombra, o pão que the matava a fome, os frutos que the saciavam a gula.

Num requinte de invenção, de terror e de crença, adorava tudo o que o impressionava pela côr ou pela fórma, ou que lançava no seu espirito as vibraçóes do medo ou da admiração. Adorava as pedras, as arvores, os animais, o trovão, a tempestade. Sentia-se infinitamente pequeno perante as grandezas que o rodeavam.

O homem, então, fez a auto-analise de si mesmo:- e o ell abstrato que vive em nós e fóra de nós, que nos transporta ao passado, que cria o futuro, que sabe prever e esperar, que a toda a parte nos leva, 
que nos faz ver o que não existe, que cria as alucinações do medo, as doçuras do prazer, os misterios da saudade, a raiva do odio e as intensidades do amor, surgiu, emfim, e, dessa analise profunda, resultou a criação da alma.

Foi enorme factor o misterio do sonho, porque no sonho existia uma outra vida. Foi ele quem deu o culto dos mortos, porque só nos sonhos eles resurgiam para a vida; foi o sonho que deu a vida de além-tumulo, porque só nos sonhos os mortos reviviam, falavam e se moviam.

Esse ell abstrato ligou-se ao corpo, como sombra que a radiosa luz desenha corpo e sombra, simbolismo dessa dualidade primitiva - e não mais pôde o homem, nem mesmo com o passar dos seculos, desfazer essa criação genial.

Depois, num arranco ideal de estetica, concretisou os seus deuses, deu-lhes fórmas segundo o seu sentir. Objectivou o idolo e gravou-o nas placas de ardosia da prehistoria, e esculpiu-o nos marmores preciosos da Roma e da Grecia. E, desde os singelos traços do selvagem até á culta e requintada pureza grega, ha, inteira, uma sequencia mental religiosa que se estende, 
que se alarga e que incide sobre tudo o que a natureza criou.

Agrupa-se num conjunto fantastico o culto dosinsectos, o das aves, o dos peixes, o dos quadrupedes; depois, véem as arvores, as plantas, as flôres, os frutos; e, por fim, a natureza morta: - as pedras, as aguas e as montanhas.

Foi o antropismo desses espiritos nascentes que trouxe a mais vasta pluralidade de cultos.

E se fiz este ligeiro esquisso da alma primitiva foi para dizer a Vossas Excelencias que, entre as sinfonias brilhantes dessa brilhante mitologia, tiveram os frutos a mais larga representação.

O homem criou os deuses segundo as necessidades do seu espirito, segundo as vibraçóes do seu sentimento.

Como o alimento era a base da vida, deu-se ao trigo, isto é, ao pão, a mais triunfal das mitologias; a mais triunfal e a mais rica: - treze divindades o protegiam, desde que a semente era lançada á terra, até que o fruto entrava na provisão dos celeiros. E tão subida e duradoira ela foi, que a palavra maturação se deriva de Matura, a divindade que alourava as cea- 
ras e as amadurecia, e messe da divindade que presidia á ceifa.

Para os trabalhos de campo havia um verdadeiro panteismo, desde Obaractor, que lavra a terra, até aos cinco deuses que hão de fortalecer os companheiros fatigados.

O trigo tem o primordial dos cultos:foi o verdadeiro deus da Roma primitiva, porque era ele quem dava força ás legióes vencedoras.

Os mexicanos divinisaram a primeira mulher que amassou o pão, e todos os povos cultos da antiguidade ofertavam aos deuses bolos sagrados feitos com a mais alva farinha. Entre os romanos, o partir do pão era a consagração do casamento religioso mais solene, e é como reminiscencia desse acto que os noivos de aldeia dão aos convidados o bolo do seu noivado.

A propria religiáo cristã deu ao pão, como simbolo, o maior valor nas cerimonias religiosas. Podemos dizer que o catolicismo fez reviver e sagrou todo o culto secular do pão.

$\mathrm{O}$ pão e o vinho que, nas missas catolicas, representam o grande misterio da transfiguração, são a mais clara sintese 
do culto do pão e do vinho, e representam nitidamente a religiáo dos frutos.

A comunhão, isto é, a entrada pura da alma no seio da igreja, é o grande sacramento que simbolisa o perdão e a redenção da alma pecadora. E' a ligação do homem com Deus, feita pela hostia, a pequenina placa de pão.

Fóra dessa significação superior, ainda para o pão se conservam as prımitivas fórmas pagãs :- oferecem-se aos santos os mesmos bolos sagrados, e, nas festas religiosas de aldeia, é a fogaça um simbolo, a fogaça que muitas vezes alia objectivamente o pão e o vinho e que conserva ainda o nome primitivo de - oferta. Nas tradiçóes populares ha o Pão por Deus, as filhós do Natal, os folares da Pascoa.

Depois vem o páo ázimo do Espirito Santo, o pão bento da Trindade e outras invocaçooses, e é dele o amuleto de Santa Quiteria de Meca.

Entre o povo não se fechará jámais o ciclo do păo. Ha mesmo uma liturgia especial para o seu fabrico. Perante o vaso onde a farinha se vai transformar em pão, a mulher faz o sinal da cruz para afugentar os espiritos malignos, e, ao ter- 
minar o trabalho, grava, com a mão aberta, uma enorme cruz sobre a massa que operou, pronunciando, ao mesmo tempo, uma invocação ao santo da sua fé para que o pão

\section{se levéde e acrescente para sustento da gente.}

São muitas as tradições populares referidas ao pão, avultando entre elas as graças a Deus, que se dão na oração que precede ou termina as refeiçóes; em nunca ter o pão com o lar voltado para cima, porque seria tombar o proprio Deus; e, sempre que o pão cái, levantá-lo com respeito e beijá-lo como se beijam os santos dos altares.

Pede-se a Deus o pão de cada dia.

Senhoras:- é pelo pão que o homem trabalha, é pelo pão que o homem aban. dona a terra querida que o viu nascer, que o homem moureja, sol a sol, na mais extenuadora violencia, porque o pão é, ao mesmo tempo, a alegria e a amargura dos pobres.

O pão e a gloria são as grandes alavancas que movem a humanidade :-o 


\section{( 23 )}

pão é o alimento do corpo, a gloria é o pão inebriante da alma.

Mas os doirados pomos que as arvores deixam pender dos seus ramos, tinham um culto á parte, porque para os produzir não era preciso o trabalho fatigante. Eram a a dadiva generosa dos deuses.

Pomona é a deusa que preside á criação dos frutos, e o mito do seu noivado e a sua volta a uma perene mocidade é, quanto a mim, o mito da primavera.

O Jardim das Hespéridas é um dos mais lindos simbolos mitologicos:- Jardim das Hespéridas era o precioso pomar onde as arvores produziam frutos de oiro, e o pomo d'oiro entra em todas as mitologias, entra nas tradiçóes populares, como simbolo de fausto e de riqueza.

Ao pomo d'oiro podemos chamar a mais alta apoteose do fruto, e é pela mais legitima analogia que a sciencia chama hesperideas a uma familia botanica que tem por tipo a laranjeira.

O pomo de Atalanta é uma interessante desforra que o homem tirou das leviandades d'Eva. Atalanta, a princeza, será noiva de quem a vencer na carreira. E' 


\section{( 24 )}

formosa. Os pretendentes chegam, correm e são vencidos. O ultimo consulta Venus e vence Atalanta, lançando no seu caminho pomos d'oiro, que ela colhe, interrompendo a carreira e deixando-se vencer.

O mito de Ceres, a deusa da agricultura, é uma lição e um exemplo. E' ela quem corre o mundo ensinando aos homens o trabalho agricola, e foi ela quem os ensinou a lavrar.

Os seus templos faustuosissimos repetem-se por toda a terra e neles lhe oferecem os homens as primicias de todos os frutos. Representa-se tendo numa das mãos uma foice e na outra un feixe de trigo e de papoulas. Cobrem-lhe o corpo seios cheios de leite.

Formoso mito é este:-Ceres, a agri. cultura, impondo aos homens o trabalho coroado pelas flôres e pelos frutos e oferecendo-lhes os multiplos seios ás necessidades da vida.

Senhoras e senhores:- Flôres e frutos são a poesia da vida, são um ciclo de amor, são a dualidade mais infinitamente bela, são a mais formosa sequencia da natureza, o mais precioso misterio, a 
mais completa e carinhosa previdencia.

Toucam-se as arvores de flôres, como manto de noivado, dando á terra a alegria das côres que faz cantar as aves e as leva a fazer os seus ninhos; e a riqueza dos perfumes, que dá aos nossos sentidos os gosos supremos da vida.

E' do noivado da terra e do sol que as flôres surgem como beijos de amor. Embalam-nas enxames de insectos chamados pelo nectar perfumado que adoça os cilios da fecundação e que véem, por incognitos designios, facilitar os misterios desse extraordinario noivado.

$\mathrm{E}$ é a esse noivado que a abelha vai buscar o doce e cristalino mel. E' desses noivados que sairam as mais preciosas plantas, as mais graciosas flôres, os mais saborosos frutos; deles foi que vieram os germens que encheram o mundo de mimo e de verdura. E tão intenso e tão vivo é o amor entre os vegetais, que ha plantas que são fecundadas pelo polen doutras plantas, situadas a rnuitas leguas, como se um laço de amor etereo e infinito as ligasse no mais estranho e impenetravel misterio.

As flôres são os sorrisos da noiva triunfante, o seu hino á criação, o seu agrade- 
cimento á natureza. E depois, como misterio de um novo misterio, as pétalas tombam, num eterno adcus, e a arvore, cobrindo-se com o seu manto esmeraldino de folhas, adquire a gravidade e a compostura de mãe.

Esboçam-se os frutos, que são os sorrisos que esse amor cristalisou, e então a arvore estende o seu manto setineo de folhas para proteger os filhos dos beijos ardentes do sol.

Dentro desses frutos, que são o ninho mais carinhoso, prepara-se uma nova geração, uma sequencia de vida, uma repre. sentação do eterno.

E' o ciclo do amor, é o ciclo da vida na sua grandeza infinita.

E esse ninho, que se avoluma e modifica pelas necessidades de um novo ser, ora tem a macieza de um seio, ora tem a dureza de um metal. E' a propria natureza vergando-se ás exigencias de uma vida que se esboça, de uma nobre sucessão que é a sua gloria mais ridente.

O fruto esboça-se, emfim, como cristalisação da flôr que, ao produzi-lo, morreu, e aparece-nos com as riquezas do desenho, com as delicadezas da côr-como 


\section{( 27 )}

se a flôr ressurgisse - com a sublimidade do perfume que é a essencia preciosa da vida.

As flôres e os frutos são os filhos dilectos do sol, são os filhos dilectos da terra. Criam-nos o sol e a terra e inventam para cada um as mais exclusivas qualida. des, os mais inesperados encantos. E' como se uma fonte de inesgotaveis recursos surgisse á luz do dia, golfando a mais comovedora riqueza, o poder da mais variada transformação.

Os frutos são uma escala infinita de fórmas, uma gama interminavel de côres, uma variedade infinda de perfumes.

Desde a pequenina planta á arvore colossal, quantos cuidados se esboçam, quantas previsóes se determinam! Os frutos ora são leves como a pena da pequenina ave que a mais leve aragem transporta, ora teem o peso e a resistencia de impenetravel armadura. Ora teem a fragilidade aparente de um floco de neve, ora teem a resistencia profunda de um bloco de aço. E todavia, ou com a fragilidade da neve ou com a resistencia do aço, existe em todos abrigada a mesma vida latente, a mesma resistencia material. Abrigam-se 
ali as vidas que hão de florir á luz do sol, como hinos triunfais de uma alvorada.

E porque não ha de ser assim, se o sol neles põe a alma e a vida, se a terra, na mais intensa das ternuras, lhes prepara a vida organica e a vida quimica que o proprio sol enriquece, aperfeiçôa e equilibra? Porque não ha de ser assim, se o mais completo laboratorio fisico-quimico para eles opera - na mais feliz das concorren. cias - as transformaçôes da mais valiosa das seivas!

Senhoras:- Ha aqui - como em toda a natureza - um misterio que ao mesmo tempo é um assombro e uma coisa infinitamente grande:- é a maneira diversa por que essa seiva se transforma não só para as qualidades invariaveis de cada fruto, mas ainda para as fórmas invariaveis e constantes de cada planta, e que nos dá o perfume valiosissimo do nardo, da violeta e da rosa, ou o aroma nauseabundo da arruda.

A seiva que produz a delicadeza dos musgos, das avencas, das orquideas, de todas as flôres, emfim, é, fundamentalmente, á mesma seiva que produz a grandeza dos 
carvalhos, a tristeza profunda dos pinheiros, a monstruosidade dos baóbás e o cinzento saudoso dos olivais.

E como é misterioso e belo o evoluir dessa seiva! - Ela sóbe das profundezas da terra, e vem, com as conjugaçóes da luz, dar as energias e durezas do lenho, a delicadeza e variedade das folhas, os misterios do crescimento. Mas, perante o pequenino botão que vai florir, ela altera a sua propria essencia:- desdobra-se nas delicadezas da côr, na subtilidade do perfume, e burila o gracioso e poderoso gineceu onde se vai operar o misterio da fecundação. Rodeia os amorosos cilios com as estrelas das pétalas e, nesse sorriso divino de côr, de luz e de aroma, produz a obra prima da natureza.

Depois, toda essa riqueza se transforma no laboratorio da mais alta quimica: - a seiva que, perante o lenho, os ramos $e$ as folhas, repete invariavel as mesmas reacçóes, dispensa ao fruto - que é a sequencia da flôr - a preferencia mais singular: protege-os e defende-os, e, quando a acção protectora é bastante, novamente modifica a sua essencia, transformando-se no amido que vai dar os assucares, donde 


\section{( 30$)$}

o perfume surge e se evola como irradiaçôes de infinita poesia.

O perfume e a doçura representam a base carateristica de todos os frutos, e a sua dosagem é o grande segredo da natureza, é a sua capital diferenciação. Para cada fruto ha uma intensidade de perfume e de doçura, como para cada flôr ha uma intensidade exacta e invariavel de côr.

Os frutos! São esses filhos do mais intenso amor, esses filhos dos mais belos noivados, que a arvore, numa abundancia magnanima, põe á disposição de quem passa.

Compreende-se e aceita-se o culto universal que se dispensa ás arvores, ás flôres e aos frutos. Compreende-se que se abençôe a arvore que à beira do caminho, no espesso da floresta, na vertente da montanha, estende para nós, graciosa e amiga, o pomo que nos mata a fome, o pomo que nos mata a sêde.

Senhoras:-Esta trindade é a mais bela das trindades universais :- a arvore, a flôr e o fruto - a vida, a côr e o alimento, capitulo da criação que encerra o que ha de mais belo. 
Senhoras:- eu sinto-me tão pequeno diante da mais pequenina erva, como diante da mais gigantesca arvore. Perante a minha observação ambas são mães replectas do mais intenso carinho.

A segurança da sua progenie é tão cuidada, que the encontro superioridades e encantos muito mais elevados que os da escala animal, se exceptuarmos alguns insectos.

A organisação do fruto é um modelo de previdencia e o mais interessante capitulo da arte na natureza; nele se desenvolvem os mais complicados problemas de composição geometrica, nele se esboçam as linhas fundamentais de todo o desenho. Tem a beleza impecavel da fórma, a gradação suave da côr, a delicadeza mais viva do perfume. E é ao lado dessas riquezas artisticas que nascem trechos capitais de previsão e ternura, preparando a dispersão das sementes.

Encheria um livro, tão grande como o mundo, a poesia da dispersão. E' que esses graciosos agentes da vida são um mundo que vai nascer, que vai surgir do nada, que vai encher a terra de côr e de 
alegria, e representam uma das mais sabias, das mais sublimes obras da criação. São os agentes que hão de cobrir a terra como onda de vida e de luz, poderosa, fecunda e criadora, que hão de produzir novas plantas, novas flôres, novos frutos, que hão de trazer ao homem a alegria e o conforto, que darão ás aves o abrigo e aos animais a abundancia; que hão de realisar, com a vida, um grande banquete da natureza, como, depois, com os seus despojos, criarāo novo banquete, donde resultará uma nova aura criadora.

E' a revivencia sobre os proprios despojos, como se o cadaver fosse preciso á alimentação e a vida da descendencia.

Sem esses despojos, a terra não seria fecunda e não mais sobre ela cantariam as aves e desabrochariam as flôres. Sem esse ressurgimento, não mais haveria a musica das fontes, a poesia da vida, a sublimidade do amor. A vida acabaria sobre a terra, como acaba sobre as crateras de um vulcáo. Se a semente, um dia, deixasse de ser fecunda, a morte cobriria a terra com as negras tintas do seu manto.

$\mathrm{Na}$ nudez hibernal da terra, onde se espalha a mais sombria tristeza, abrigam 


\section{( 33 )}

as sementes o germen latente da sua potencia criadora. E ela virá, grande, dominadora e bela, cheia de encantos e de ful. gores.

E' a natureza quem cria, e é o vento quem faz a sementeira. E o vento, nesse acto bemfazejo, corre em todas as direcçóes para que a obra seja perfeita.

E como é variada e rica essa deliciosa obra de amor!

Ha sementes quasi microscopicas que tombam junto da planta mãe para germinarem e crescerem á sua sombra protectora, ao passo que outras caem com o proprio fruto, indiferentemente, e esperam, no seu isolamento, as humidades do inverno e o sol da primavera.

Outras prendem-se ao pêlo dos animais e ao fato dos homens, para que a sua dispersão seja mais vasta. Umas encurvam os seus estiletes, para que a mais leve aragem as transporte, outras esperam as asperezas do vento, para se levantarem em ondas de disseminação. Ha vagens e siliquas, com dehiscencia violenta, projectando para longe as sementes que protegiam; e, esse arremesso, que á primeira vista parece um rasgo de inaudito despre- 


\section{( 34$)$}

zo, é uma benção, é um beijo de amor:é que a planta mãe exgotára o terreno e tornára-o improprio para a alimentação dos filhos.

Depois véem os frutos compostos, de multiplas sementes, vem a alcachofra como tipo, com o seu fruto coberto de espinhos protectores, coroado pela mais alva cabeleira, como calice bemdito espumando flócos de amor. Ao abrir-se, é o vento quem desloca e arranca as sementes, é o vento que, tomando-as pelos brancos penachos, as faz voar para longe, como aves em busca de outro clima.

E' o fruto do pinheiro, um dos mais fortes, mais interessantes e mais complexos dos frutos, abrindo os loculos muitas vezes protegidos e deixando cair as sementes duplamente aladas, para que o vento as faça voar e as deixe ir sonhando, sonhando, na desordenada ancia de encherem o mundo inteiro.

São os esporos, emfim, conservando a mais ampla vitalidade latente, e esperando, indiferentemente, as condições favoraveis ao seu desenvolvimento, ou durante a rapidez de um dia, ou durante a morosidade de un seculo. 
Mas como nem toda a semente que cai na terra ha de produzir outra planta, porque diversos agentes a destroem;--então a planta mãe, previdente, numa abun. dancia imprevista, multiplica os seus frutos para que fique assegurada e certa a sua linha de sucessão.

A fórma dos frutos e das sementes representa o mais belo capitulo de arte fantastica, desde a pureza da linha recta á curva mais doce e mais harmonica, á fórma caprichosa que recorda, indiscutivelmente, uma formação animal. Foi nela que o homem achou as linhas da mais pura geometria, e foi ela que the sugeriu as primitivas obras de arte, as graciosas curvas que representam a delicadeza e grandeza da fórma, a pureza das rectas que nos deram todo o encanto, toda a grandeza, toda a sublimidade da pureza ogival. Foi ali que ele achou a ligação das fórmas e das côres, a queda suave e verdadeira de uma linha sobre outra linha, o que resume tudo o que em arte ha de mais belo; e de lá trouxe a galantaria das bases comprimidas, dos envasamentos mais complicados. 
Depois da poesia da dispersāo, vem a germinação das sementes. E' outro belo e vasto capitulo da criação.

A semente é a vida latente que vôa, que se arrasta, que flutua, esperando ligar-se á terra ou á agua, á frescura da sombra ou ás ardencias do sol, conforme o meio em que vai desenvolver-se. E' a ancia da vida, é a poesia do ámanhā. Abriga no seio o germen que vai nascer e, microscopica ou gigantesca, encerra o poder mais vigoroso da vida.

As suas dimensōes, sob o ponto de vista economico e humano, são aquelas que precisamente devem ter para nutrirem o novo ser até que ele possa arrancar da terra que o cerca a sua indispensavel alimentação. Contém as reservas ricas e condensadas como em nenhuma outra escala da vida organica.

Perante a acção da luz, do calor e da humidade transforma o seu desenho, acorda, alarga-se, vive, sente, divide-se, prolonga-se, emfim, na parte que ha de viver no ar - as folhas --, na parte que ha de viver na terra - as raizes.

Se nasce num lugar sombrio, a gemula nascente ergue-se, doidamente, em 
busca da luz do sol que ha de dar-lhe a força e poder. Se a humidade the falta, comprime o seu crescimento para que a evaporação não a mate.

Se descessemos á vida microscopica dos liquens, das algas e dos fungos, e se bem podessemos entendê-la, seriam infi. nitas as estrofes dos seus infinitos poemas.

A semente é um rnundo disperso, perdido, adormecido, esperando ós beijos do sol para nascer e florir.

E' um simbolo, e é uma vida; é um nada, e representa um mundo.

Senhoras : - a duração dos frutos era limitada; era preciso conservá-los, como base da alimentação. Foi nessas pesquizas que o homem achou elementos de grande valor. Os frutos amadurecidos que o homem não aproveitava, que as aves não comiam ou que os insectos não inutilisavam, ficava-os namorando o sol; um raio da sua luz sobre eles incidia com carinhoso afago, querendo ampará-los na vida que se extinguia.

Oraio do sol incidia, e os frutos deixavam. se tombar, transformando a sua propria essencia, e adquirindo uma longa duração. 
A primeira industria que aos frutos se póde referir ensinou-a a natureza tendo o sol por operario.

Foi assim que o sol ensinou o homem a fazer uma deliciosa provisão de frutos secos, a que a alma popular ainda hoje dá a pitoresca designação de frutos passados - passados pelo sol.

Depois das delicadezas do sol, véem as subtilezas de Noé. Noé esmagou as uvas para guardar o seu suco predilecto. $\mathrm{O}$ liquido, inesperadamente, fermentou, e o vinho fez a sua aparição no mundo. Noé provou, gostou e bebeu; bebeu até cair nas alucinaçóes da embriaguez.

$\mathrm{O}$ vinho teve depois o seu culto. Bacho foi o sacerdote magno. Como Moisés, que, com a sua vara, fazia brotar fontes da mais cristalina agua, Bacho, com o copo ou com o tirso, fazia brotar fontes do mais perfumado vinho.

Bacho foi o sacerdote espiritual da nova bebida; Sileno, o satiro, representava o que nela havia de mais grosseiro. Pinta-se com os esgares da grosseira embriaguez: - grotesco, coroado de parras, desordenado, perdida a gravidade e cavalgando o tonel, repositorio da loucura. 
Dessas fases grosseiras do vinho alguma coisa de delicado ficou: - ficaram as libaçôes leves e espirituais que os homens escolheram para trocarem entre si os votos mais solenes de fraternidade e de afecto, e onde a pureza do liquido deve corresponder á pureza das intençôes.

Ha um poema biblico da mais alta espiritualisação:---é o Cantico dos Canticos. Canta-se nele o mel, o amor e os frutos. O simbolismo desse poema é a mais alta consagraçĩo do fruto.

Senhoras:- Os frutos deram ao homem as primeiras noções para a sua ceramica, e os frutos, as folhas e as flôres, as notas fundamentais de toda a estetica. A ceramica nasceu da imitação de certos frutos de casca resistente, ainda hoje vulgarmente empregadós para recipientes de liquidos.

O homem fixou a fórma deles, e depois, imitando-os na faiança, na porcelana, no cristal, operou verdadeiras maravilhas. Arrancou notas de equilibrio e de beleza que fazem a delicia dos olhos.

Mais tarde, querendo espiritualisar os frutos - estilisou-os. Enriqueceu a arqui- 


\section{(40)}

tectura, a ourivesaria, a tapeçaria, chamou-os ao seu convivio em todas as manifestaçóes da vida espiritual, como antes os chamára ás necessidades organicas da sua vida.

Não podia ser mais alta a apotéose do fruto.

Meus senhores:-A pomicultura é uma arte antiga. Trezentos anos antes de Cristo já Teófrasto refere as frutas da Grecia, embora em numero limitado, e cita entre outras frutas quatro variedades de peras, uma das quais chegou até nós:-é a Cuisse de Madame.

Catão aconselha a cultura dos frutos de inverno, e Plinio já menciona quarenta e uma variedades de peras.

A França é a eterna mãe dos bons frutos, e foi nela que se produziram as variedades mais estimadas em toda a serie, embora os obtentores, no decorrer dos seculos, fossem em numero limitado.

Nos grandes mosteiros e abadias é que aos frutos se dispensou a maior atenção, e foi aí que se organisaram as melhores colecçóes e se definiram as selecçōes mais cuidadas. 


\section{(4I)}

A Renascença, que tocou todas as notas do sentimento humano, tambem influiu na criação dos pomares. Agruparam-se series dispersas, procurou aperfeiçoar-se a cultura, mas só no seculo XVII se esboça, com certo rigor, a pomicultura scientifica.

O grande propagandista da pomicultu. ra foi La Quintinie, o grande jardineiro de Luiz XIV; cria os pomares de Versathes, que, com os seus jardins modelares, entram em moda em todo o mundo, levando o entusiasmo pela cultura frutifera e lançando-a na mais bela das suas fases.

E para que esse entusiasmo não esmorecesse, praticavam-se as podas cativas desenhando as mais caprichosas fórmas. Abriam-se arruamentos em contra-espaldeira, desdobrando-as em leque na mais impecavel simetria; levantavam-șe piramides dos desenhos mais esbeltos; criavam-se, emfim, a arquitectura pomicola e a verdadeira pomologia. Faziam-se obras de arte que viviam e que sentiam.

Contra as brancas paredes das habitaçốes esbatem-se espaldeiras das arvores mais queridas, e os frutos crescem entre flôres, formando um conjunto ideal. 
No meio dos canteiros dos mais belos jardins levantam-se arvores frutiferas, com os variados encantos de fórma que o homem the soube dar, e os mais preciosos frutos corôam a policromia das flòres. E, como se isso não bastasse, ligou-as com festôes de rosas, com hinos de alegria.

Uma nova era surge para os frutos e para as flôres:- é quando o homem vai em auxilio da natureza, e, como que num poder sobrenatural, opéra fecundaçóes artificiais, e produz por selecçāo, sementeira e enxertia, frutos de novos caratéres, de ineditas qualidades.

E' brilhantissima essa nova era de criação:-o homem domina a natureza e obriga-a a produzir segundo a sua vontade. As flôres duplicam as pétalas, encurvam-nas, formam franjas do mais raro recórte, ligam-se ou ordenam-se por novas disposiçôes e novas côres, e novas tonalidades, novos desenhos, emfim, surgem á luz do dia.

Fecham-se series novas, criam-se variedades e novos capitulos véem enriquecer as curiosidades da botanica.

E' Burbank, na America, obtendo, pelos seus sabios cruzamentos, frutos de novo 
desenho c arvores variadas da mais pujante e sucessiva frutificação. E' Nomblot, Leroy, Van Houte, Cochet, Pcrnet, Dickson e tantos outros dominando a natureza e fazendo das flôres o mais bclo jogo de espirito e de educação.

São esses novos pontifices mostrando á natureza particularidades de que ela se esquecera, dando ao mundo uma nova poesia de fórma e de côr, táo bela e tão grande como os cantos dos maiores poemas.

As moradas e os jardins dos homens poderẫo transformar-se em estancias d'arte e de prazer. A mão educada dará ás arvores requintes de fórma, de delicadeza e de pujança, e a fantasia das colunas seiscentistas, cobertas de flòres e de frutos, não será mais uma frase convencional de fria pedra, mas uma realidade palpitando, vivendo e crescendo.

Para os salóes mais luxuosos ha plantas da mais nobre delicadeza, levando a frescura, o sentimento e a vida que nenhuma obra d'arte póde dar; e sobre a mesa dos banquetes poderão alinharse - por esmerada cultura - pequeninas arvores cobertas de frutos, que 
farão a alegria e a admiração dos convivas.

Senhoras:- O homem, um dia, pensou em regressar á alimentação primitiva. Viu nisso um ressurgimento de raça.

Primeiro, aboliu as carnes e alimentouse de produtos vegetais. Depois, foi mais longe: - fez-se frutivoro.

Chama-se a isto - implantar a poesia na alimentação. Começou por um motivo de sentimento, e procura vencer com um hino de alegria, estendendo aos animais a sua acção protectora.

Realisado esse idealismo, ter-se-ia inscrito um grande capitulo de bondade, uma grande obra de bem:- não mais o excitariam as digestóes laboriosas da carne, não mais o alucinariam os éteres perfumosos dos vinhos, não mais na sua mesa fumegariam as grandes peças de vianda, não mais o corso ferido mugiria, dolororo, saudades do mundo, nem as aves tombariam ao tiro do caçador, nem a rez ajoelharia sob a choupa do magarefe. As aves teriam no espaço a vida e a liberdade, e os peixes relampejariam nas aguas as suas scintilaçóes de metal, sem receio do arpeu 


\section{( $\left.4^{5}\right)$}

ou do anzol do pescador. Haveria a paz para os animais, que nunca mais, nunca mais, seriam abatidos para satisfação da gula humana.

Se este belo ideal se transformasse numa realidade seria a mais bela e completa obra d'arte, de tudo o que de belo a na. tureza produziu: - as flôres e os frutos, como sinfonia de encanto, conjugariam a beleza da sua fórma, a intensidade do seu colorido, e em toda a casa se evolaria a magna suavidade dos seus perfumes.

Seria este, certamente, o mais belo dos banquetes da natureza. E o homem, contemplando e abençoando essa maravilha, veria nessas flôres e nesses frutos que o comoviam, as mais puras dinamisações da luz do sol e o que ha de mais belo na vida organica.

$O$ frutivorismo é um novo sacerdocio que nasce, uma renovação de culto que começa.

A pomolatria é uma nova religião que chega, com sectarios de vivo explendor, e, como no catolicismo, onde a hostia se adora e se ingere, o frutivoro adora e devora o proprio deus, numa fé de ressurgimento bem digna de admiração. 
Depois desta eterna e quasi biblica apoteose do fruto, que mais poderemos dizer?

Se o homem, desde os primordios da sua vida, o adora e aperfeiçôa, que faremos nós, homens cultos, senão seguir o eterno caminho?

Senhoras:- Neste momento, neste recinto, e perante um altar onde Ceres, pela mão da Abundancia, derramou, tão generosamente, tantos e tão belos frutos, eu sinto-me reviver, sinto-me feliz e transportado a uma das maiores festas da grande mitologia, porque nada falta hoje a este culto pagão.

De longes terras concorreram os sacerdotes com os mais belos frutos dos seus pomares, e vieram, na sua religiosa romagem, depô-los no altar da beleza. E os que não vieram mandaram, como oferta aos deuses, as mais belas primicias do seu precioso trabalho.

Os frutos surgiram entre flôres, á luz dos nossos olhos, com a riqueza pujante da fórma e da côr, expandindo, magnanimos, os efluvios da sua alma, que sāo a suprema delicadeza dos seus perfumes. 
Nada faltou a esta festa pagã :- nem a crença, nem a fé, nem o fulgor do mais delirante entusiasmo.

Estamos adorando a Terra perante o faustoso altar dos frutos e das flôres. $\mathrm{Na}$ nossa alma vibra, nitida, uma oração á côr e ao perfume, e sentimo-nos pequenos perante este caso de surpreendente realidade.

Senhoras:-Aoterminar esta festa quasi biblica - que ha de deixar na alma de todos nós a mais consoladora das saudades, - onde os frutos e as flôres brilham como astros - senhoras, eu lanço esta benção em nome de todos nós:

Abençoada seja a terra que táo belos frutos produziu; abençoado e louvado seja o homem que tão bem os cultivou. 

PALAVRAS QUE PRECEDERAM A LETURA DA

Pokslat uOS Frutas 

Senhor Presidente da Republica l'ortuguésa

AV. Ex. a, senhor Presidente, as saudacốes mais carinhosas do meu coraçāo. Näo tenho outra frase mais intima, nem, ao mesmo tempo, mais grande, para saudar o mais ilustre portugue's do meu tempo, a alma patriotica mais sentida, o homem de sciencia mais vasta, o escritor que tem a veneraçáo do mundo inteiro, o homem cuia vida é o mais são, o mais belo, o mais diamantino dos excmplos.

Eu saúdo em V. Ex. a o homem que possue todas essas virtudes e qualidades, e que ao meu espirito assombrido tem a pureza e a grandeza de um patriarca biblico.

Estes dizeres, que aos olhos do homem 
terão a banalidade de simples convençāo, representam, na sua simplicidade e pureza, loda a vibração da minha alma, tudo o que nela existe de mais carinhoso e afectivo.

V. Ex." que na minha vida inteira tem sido $\mathrm{um}$ dilecto amigo, sabe muito bem quanta sinceridade elas representam.

Senhor Presidente:-a vinda de $V$. Ex. a á minha terra querida, que é o sonho da minha vidü e a luz do meu sonho, á terra que como V. Ex. a hoje viu, sabe ser grande na sua pequene-, que tem rasgos de grandera e aspiraçóes a exmplo, que é uma das mais lindas deste formoso pain, que $V$. Ex. a tem engrandecido com os ful. gores do seu prodigioso saber, senhor Presidente, a minha terra, agradecida, curva o joelho saudando a vinda de V. Ex. ${ }^{a}$ como a suprema gloria a que ela podia as pirar. 
Senhor Minstro do lomento

Na minha saudaçäo a $V$. Ex. a rai a nota de maior reconhecimento pela minha terra e por mim.

V. Ex." hourou Alcobaça escolhendo-a para séde de uma exposiçāo de frutos, $e$ cla, creio-o, cumpriu o seu dever.

Salido V. Ex. ${ }^{a}$ pela realisação do seu desejo. que a cooperação de muitas vontades tornou brilhante, e felicito o meu pair por ver, emfim, inauguradas novas formas de progresso agricola e rasgados novos horisontes de luz.

Senhor Ministro: - eu näo posso, nesle momento, deixar de juntar á minha saudaçäo uma nota de pungente saudade. E' que 
o nome de I'. Ex. a não apareceu ao meu espirito no vulgar isolanento de um nome. Surgiu como uma ideia entre os nomes de Ricardo Severo, José Forles, Rocha Pei. xolo e Fonseca Cardoso, que formaram o primordial dos grupos para quem o renascer de Porlugal assomava. Foi perante essa multipla vontade, perante esse esforço titanico, perante esse glorioso trabalhar, que o nome de V. Ex. a surgiu á luz do meu espirito.

$E$ depois, como suprema gloria minhu, achava-me ligado, pelos laços da mais sincera amisade, a esse grupo de trabalhadoves incançaveis. Assisti ao nascer da "Portrgalian, o monumento imperecivel que desse grupo saiu, e tive a honta de ser o mais modeslo dos seus operatios.

E' por isso, senhor ministro, que eu, tecordando esse glorioso tempo, não podia deixar de registat uma funda saudade pelos mortos queridos, e de saudar na pessoa de V. Ex. a os estremecidos amigos que ain. da vivem.

Senhor Ministro: - em nome da minha terra, em nome da pomologia portuguésa, em nome de todos aqueles em quem o senlimento patriotico existe, eu felicito $I$. 
( 55 )

Ex. ${ }^{a}$ pelo brilho deste concurso, e deixo in nesla felicitação todo o meu carinhoso afecto. 



\section{- Festa dos Frutos .}

PROMOVIDA POR M. VIEIRA NATIVIDADE E SEUS FII HOS

- PROGRAMA •

I POESIA DOS FRUTOS, palavras lidas por M. VIEIRA NATIVIDADE.

II VERSOS de Bulhão Pato, por JOÃO PINA.

III DISCURSO, pelo Ex.mo $S_{R}$. JOÃo SERRAS CONCEIÇÃO.

IV VERSOS de Antonio Correia de Oliveira, por JOAQUIM NATIVIDADE.

V DISCURSO pelo Ex. ${ }^{m o} S_{R}$. haNUEL MONTEIRo, ilustre Ministro do Fomento.

NUMEROS DE MUSICA ESCOLHIDA, PEL.I BANDA DE MARINHEIROS DA ARMADA 


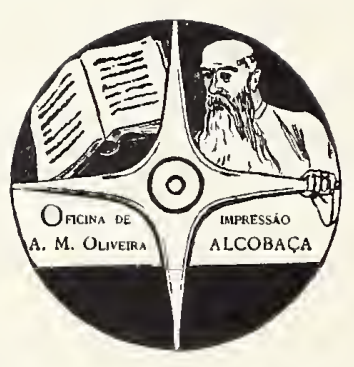




\section{.}





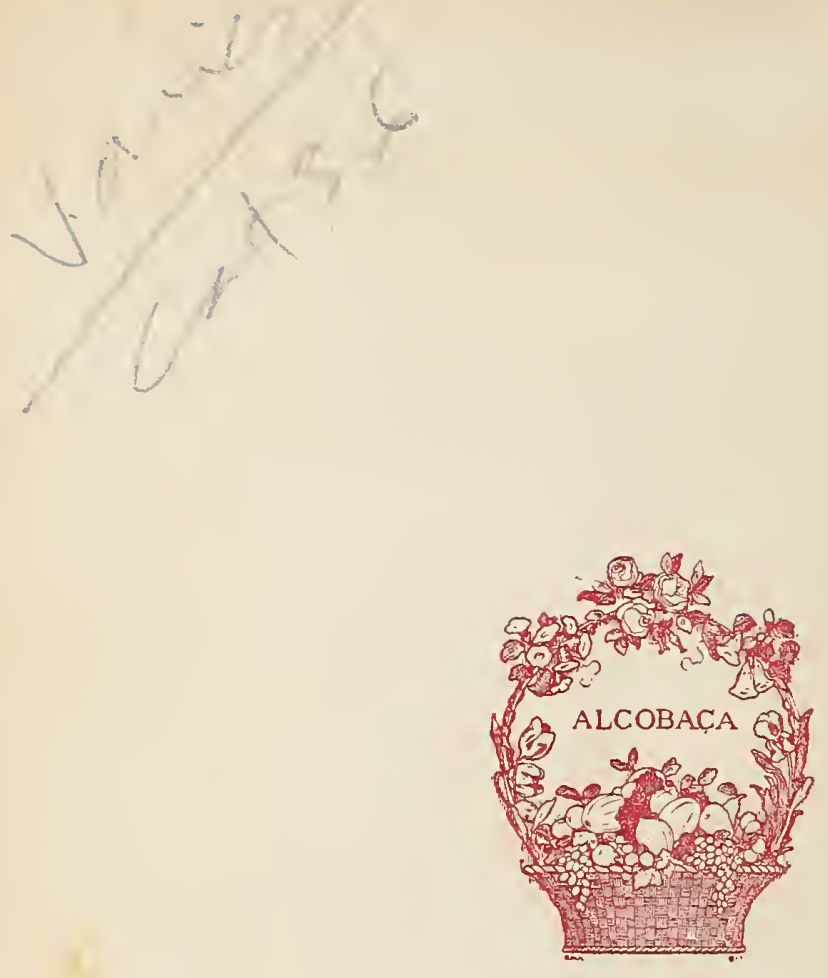